\title{
Structure and magnetic properties of copper(II) carboxylate with pyridyl-substituted nitronyl nitroxides
}

\author{
Hsin-Huang Lin ${ }^{\mathrm{a}}$, Ho-Hsiang Wei ${ }^{\mathrm{a}, *}$, Gene-Hsiang Lee ${ }^{\mathrm{b}}$, Yu Wang ${ }^{\mathrm{b}}$ \\ a Department of Chemistry, Tamkang University, Tamsui 25137, Taiwan, ROC \\ b Instrumental Center, College of Science, National Taiwan University, Taipei, Taiwan, ROC
}

Received 27 March 2001; accepted 3 August 2001

\begin{abstract}
The synthesis, crystal structure and magnetic properties of four new copper(II) carboxylate complexes with pyridyl-substituted nitronyl nitroxides, $\quad\left[\mathrm{Cu}_{2}\left(\mu-\mathrm{ClCH}_{2} \mathrm{CO}_{2}\right)_{2}\left(\mathrm{ClCH}_{2} \mathrm{CO}_{2}\right)_{2}(\mathrm{NITpPy})_{2}\left(\mathrm{H}_{2} \mathrm{O}\right)_{2}\right] \mathrm{CH}_{3} \mathrm{OH} \quad(\mathbf{1}), \quad\left[\mathrm{Cu}\left(\mathrm{Cl}_{2} \mathrm{CHCO}_{2}\right)_{2}(\mathrm{NITpPy})_{2}\left(\mathrm{H}_{2} \mathrm{O}\right)\right]$ (2), $\left[\mathrm{Cu}\left(\mathrm{Cl}_{3} \mathrm{CCO}_{2}\right)_{2}(\mathrm{NITpPy})_{2}\left(\mathrm{H}_{2} \mathrm{O}\right)\right](3)$ and $\left[\mathrm{Cu}\left(\mathrm{Cl}_{2} \mathrm{CHCO}_{2}\right)_{2}(\mathrm{NITmPy})_{2}\left(\mathrm{H}_{2} \mathrm{O}\right)_{2}\right]$ (4) (NITpPy = 4,4,5,5-tetramethyl-2-(4-pyridyl)-2imidazoline- $N^{1}$-oxy $N^{3}$-oxide, NITmPy $=4,4,5,5$-tetramethyl-2-(3-pyridyl)-2-imidazoline- $N^{1}$-oxy $N^{3}$-oxide) are reported. Complex 1 has a dimeric structure where two copper ions are doubly bridged by four oxygen atoms from two $\mu-\mathrm{ClCH}_{2} \mathrm{CO}_{2}^{-}$ions. Complexes $\mathbf{2}$ and $\mathbf{3}$ are mononuclear, the copper(II) ion has five coordination with square-pyramidal symmetry. In complex $\mathbf{4}$, the copper(II) ion has distorted-octahedral six coordination. Temperature dependence studies of the $\chi_{\mathrm{m}} T$ values of complexes 1-4 revealed that 1 exhibits a strong intramolecular metal-metal antiferromagnetic interaction and a weak intramolecular metal-nitroxide antiferromagnetic coupling, $\mathbf{2}$ and $\mathbf{3}$ exhibit a weak intramolecular metal-nitroxide antiferromagnetic coupling, while $\mathbf{4}$ possesses weak ferromagnetic exchange interactions between metal and NITmPy. A simple spin polarization model has been used to justify the observed magnetic exchange interactions between $\mathrm{Cu}(\mathrm{II})$ and radical ligands. (C) 2001 Elsevier Science Ltd. All rights reserved.
\end{abstract}

Keywords: Copper(II) carboxylate complexes; Pyridyl-substituted nitronyl nitroxides; Antiferromagnetic coupling; Spin polarization

\section{Introduction}

The magnetic properties of a large number of stable organic $N$-oxyl $N^{\prime}$-oxides (nitronyl nitroxides) and their metal complexes have been studied, especially in order to understand the factors that influence the magnetic exchange interactions between the metal ion and the radical centers [1-8]. The magnetic metal complexes with pyridyl-substituted nitronyl nitroxides have been intensively studied $[1,2,4-19]$ in the past decade. These radicals are especially attractive due to their donor atoms and their ability to assemble extended coordination geometries with changing magnetic coupling. The heterospin systems consisting of organic free radicals and paramagnetic metal ions constitute one of the most

\footnotetext{
* Corresponding author. Tel.: + 886-2-2620-2821; fax: + 886-22620-9924.

E-mail address: tkwei@mail.tku.edu.tw (H.-H. Wei).
}

promising design strategies for high Curie-temperature molecular-based magnets $[1,20]$. The observed magnetic properties of the metal-radical complexes were clearly explained in terms of the spin polarization mechanism of $\pi$-electrons [16,21].

In magnetic copper(II)-nitronyl nitroxide radical heterospin systems, the sign and magnitude of the spin coupling between the two components depends not only on the periodicity of the radical ligand $\pi$ orbital, but also strongly on the orbital occupied by the unpaired d-electrons of the copper ion. The copper(II) ion has one unpaired electron in the $\mathrm{d}_{x^{2}-y^{2}}$ orbital that has $\sigma$ magnetic orbital character, its complexes are expected to display quite different magnetic behavior.

Along this line, we wish to report here the structural and magnetic characterization of $\left[\mathrm{Cu}_{2}\left(\mu-\mathrm{ClCH}_{2} \mathrm{CO}_{2}\right)_{2}\right.$ $\left.\left(\mathrm{ClCH}_{2} \mathrm{CO}_{2}\right)_{2}(\mathrm{NITpPy})_{2}\left(\mathrm{H}_{2} \mathrm{O}\right)_{2}\right] \mathrm{CH}_{3} \mathrm{OH} \quad(\mathbf{1}), \quad\left[\mathrm{Cu}\left(\mathrm{Cl}_{2}-\right.\right.$ $\left.\left.\mathrm{CHCO}_{2}\right)_{2}(\mathrm{NITpPy})_{2}\left(\mathrm{H}_{2} \mathrm{O}\right)\right] \quad(2), \quad\left[\mathrm{Cu}\left(\mathrm{Cl}_{3} \mathrm{CCO}_{2}\right)_{2}(\mathrm{NIT}-\right.$ $\left.\mathrm{pPy})_{2}\left(\mathrm{H}_{2} \mathrm{O}\right)\right]$ (3) and $\left[\mathrm{Cu}\left(\mathrm{Cl}_{2} \mathrm{CHCO}_{2}\right)_{2}(\mathrm{NITmPy})_{2}-\right.$ $\left.\left(\mathrm{H}_{2} \mathrm{O}\right)_{2}\right]$ (4) (Scheme 1). 


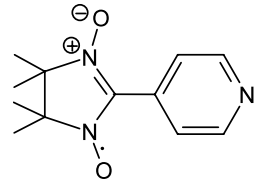

NITpPy

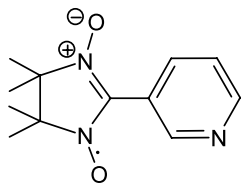

NITmPy
Scheme 1.

\section{Experimental}

\subsection{Preparation of the ligands and the copper(II) carboxylates}

The pyridyl-substituted radicals NITpPy $(4,4,5,5$-tetramethyl-2-(4-pyridyl)-2-imidazoline- $N^{1}$-oxyl $\quad N^{3}$-oxide) and NITmPy (4,4,5,5-tetramethyl-2-(3-pyridyl)2-imidazoline- $N^{1}$-oxyl $N^{3}$-oxide) were prepared and purified according to literature methods [22]. Copper(II) carboxylates, $\left[\mathrm{Cu}\left(\mathrm{RCO}_{2}\right)_{2}\right]\left(\mathrm{H}_{2} \mathrm{O}\right)_{2}$, where $\mathrm{R}=$ $\mathrm{ClCH}_{2}-, \mathrm{Cl}_{2} \mathrm{CH}-$ and $\mathrm{Cl}_{3} \mathrm{C}_{-}$, were prepared as described previously [23]. Copper(II) nitrate trihydrate (6 mmol) and the carboxylic acid $(12 \mathrm{mmol})$ were dissolved in approximately $100 \mathrm{~cm}^{3}$ of water at $\mathrm{pH} 5-6$. The solution was allowed to stand at $25{ }^{\circ} \mathrm{C}$ for several days, giving precipitated products that were filtered.

\subsection{1. $\left[\mathrm{Cu}_{2}\left(\mathrm{\mu}-\mathrm{ClCH}_{2} \mathrm{CO}_{2}\right)_{2}\left(\mathrm{ClCH}_{2} \mathrm{CO}_{2}\right)_{2}(\mathrm{NITpPy})_{2}-\right.$} $\left.\left(\mathrm{H}_{2} \mathrm{O}\right)_{2}\right] \mathrm{CH}_{3} \mathrm{OH}(\mathrm{1}),\left[\mathrm{Cu}\left(\mathrm{Cl}_{2} \mathrm{CHCO}_{2}\right)_{2}(\mathrm{NITpPy})_{2}\left(\mathrm{H}_{2} \mathrm{O}\right)\right]$ (2), $\left[\mathrm{Cu}\left(\mathrm{Cl}_{3} \mathrm{CCO}_{2}\right)_{2}(\mathrm{NITpPy})_{2}\left(\mathrm{H}_{2} \mathrm{O}\right)\right]$ (3) and

$\left[\mathrm{Cu}\left(\mathrm{Cl}_{2} \mathrm{CHCO}_{2}\right)_{2}(\mathrm{NITmPy})_{2}\left(\mathrm{H}_{2} \mathrm{O}\right)_{2}\right]$ (4)

Copper(II) carboxylates (3 mmol) and NITpPy or NITmPy $(6 \mathrm{mmol})$ were dissolved in $20 \mathrm{~cm}^{3}$ of methanol $\left(\mathrm{CH}_{3} \mathrm{OH}\right)$ at $25{ }^{\circ} \mathrm{C}$. The mixtures were stored at $25{ }^{\circ} \mathrm{C}$ for several days, and then dark-blue wellshaped crystals suitable for X-ray diffraction were collected. Satisfactory microanalyses for complexes 1-4 were obtained. Anal. Found: C, 38.1; H, 4.6; N, 8.2. Calc. for $\mathrm{C}_{33} \mathrm{H}_{48} \mathrm{Cl}_{4} \mathrm{Cu}_{2} \mathrm{~N}_{6} \mathrm{O}_{15}$ (1): C, 38.2; H, 4.6; N, 8.1\%. Anal. Found: C, 41.6; H, 4.5; N, 10.5. Calc. for $\mathrm{C}_{28} \mathrm{H}_{36} \mathrm{Cl}_{4} \mathrm{CuN}_{6} \mathrm{O}_{9}$ (2): C, 41.6; H, 4.5; N, 10.4\%. Anal. Found: $\mathrm{C}, \quad 38.4 ; \mathrm{H}, 3.9 ; \mathrm{N}, \quad 9.6$. Calc. for $\mathrm{C}_{28} \mathrm{H}_{34} \mathrm{Cl}_{6} \mathrm{CuN}_{6} \mathrm{O}_{9}$ (3): C, 38.5; H, 3.9; N, 9.6\%. Anal. Found: C, 40.9; H, 4.5; N, 10.0. Calc. for $\mathrm{C}_{28} \mathrm{H}_{38} \mathrm{Cl}_{4} \mathrm{CuN}_{6} \mathrm{O}_{10}$ (4): C, 40.8; H, 4.6; N, $10.0 \%$.

\subsection{Physical measurements}

X-band EPR spectra at $300 \mathrm{~K}$ for the complexes in the form of powder and in $\mathrm{CH}_{2} \mathrm{Cl}_{2}$ solutions were recorded in a Bruker ESC-106 spectrometer. The magnetic susceptibilities were carried out on polycrystalline samples with a fully automated MPMS superconducting quantum interference device (SQUID) magnetometer working in the range $4-300 \mathrm{~K}$ under a magnetic field of $1 \mathrm{~T}$. Diamagnetic corrections were estimated from Pascal's constants [24].

\subsection{Crystallography}

X-ray crystal data for complexes 1, 4 and 2, 3 were collected in a Siemens P4 and in an Enraf-Nonius CAD4 diffractometer, respectively, equipped with graphite-monochromatized Mo $\mathrm{K} \alpha$ radiation $(\lambda=$ $0.71073 \AA$ ) and $2 \theta-\theta$ scan mode. The unit-cell parameters were determined from $2.2<\theta<25.0^{\circ}$ for $\mathbf{1}$, $1.64<\theta<22.47^{\circ}$ for $2,1.61<\theta<22.49^{\circ}$ for 3 and $2.08<\theta<24.99^{\circ}$ for 4 . $N$ independent reflections and $N_{\mathrm{o}}$ with $I>2.0 \sigma(I)$ were observed. The details of data

Table 1

Crystal data and structure refinement parameters for complexes 1-4

\begin{tabular}{|c|c|c|c|c|}
\hline & 1 & 2 & 3 & 4 \\
\hline Empirical formula & $\mathrm{C}_{33} \mathrm{H}_{48} \mathrm{Cl}_{4} \mathrm{Cu}_{2} \mathrm{~N}_{6} \mathrm{O}_{15}$ & $\mathrm{C}_{28} \mathrm{H}_{36} \mathrm{Cl}_{4} \mathrm{CuN}_{6} \mathrm{O}_{9}$ & $\mathrm{C}_{28} \mathrm{H}_{38} \mathrm{Cl}_{4} \mathrm{CuN}_{6} \mathrm{O}_{10}$ & $\mathrm{C}_{28} \mathrm{H}_{34} \mathrm{Cl}_{6} \mathrm{CuN}_{6} \mathrm{O}_{9}$ \\
\hline Formula weight & 1037.68 & 805.97 & 824.01 & 874.85 \\
\hline Crystal system & monoclinic & triclinic & triclinic & triclinic \\
\hline Space group & $P 2_{1} / c$ & $P \overline{1}$ & $P \overline{1}$ & $P \overline{1}$ \\
\hline \multicolumn{5}{|l|}{ Unit cell dimensions } \\
\hline$a(\AA)$ & $14.826(2)$ & $12.367(3)$ & $7.5560(12)$ & $12.675(2)$ \\
\hline$b(\AA)$ & $7.2352(9)$ & $12.396(4)$ & $10.038(2)$ & $12.724(3)$ \\
\hline$c(\AA)$ & $22.806(4)$ & $24.026(3)$ & $12.298(3)$ & $24.374(5)$ \\
\hline$\alpha\left({ }^{\circ}\right)$ & 90 & $90.12(3)$ & $77.44(2)$ & $88.76(3)$ \\
\hline$\beta\left({ }^{\circ}\right)$ & $92.026(13)$ & $104.39(2)$ & $79.63(2)$ & $75.06(2)$ \\
\hline$\gamma\left({ }^{\circ}\right)$ & 90 & $90.36(3)$ & $87.119(13)$ & $85.32(3)$ \\
\hline$Z$ & 3 & 4 & 1 & 4 \\
\hline$D_{\text {calc }}\left(\mathrm{g} \mathrm{cm}^{-3}\right)$ & 1.808 & 1.5011 & 1.528 & 1.535 \\
\hline$F(000)$ & 1362 & 1660 & 425 & 1788 \\
\hline Crystal size (mm) & $0.52 \times 0.36 \times 0.21$ & $0.70 \times 0.40 \times 0.05$ & $0.75 \times 0.56 \times 0.47$ & $0.65 \times 0.25 \times 0.05$ \\
\hline$N$ & 4307 & 9290 & 9894 & 3127 \\
\hline$N_{\mathrm{o}}$ & 4487 & 9290 & 9894 & 3389 \\
\hline$R_{1}$ & 0.0579 & 0.0581 & 0.0810 & 0.0610 \\
\hline$R_{\mathrm{w}}$ & 0.1313 & 0.1597 & 0.2057 & 0.1452 \\
\hline
\end{tabular}


Table 2

Selected bond lengths $(\AA)$ and bond angles $\left(^{\circ}\right)$ for complexes $\mathbf{1}$ and $\mathbf{2}$

\begin{tabular}{|c|c|c|c|}
\hline \multicolumn{4}{|c|}{$\left[\mathrm{Cu}_{2}\left(\mu-\mathrm{ClCH}_{2} \mathrm{CO}_{2}\right)_{2}\left(\mathrm{ClCH}_{2} \mathrm{CO}_{2}\right)_{2}(\mathrm{NITpPy})_{2}\left(\mathrm{H}_{2} \mathrm{O}\right)_{2}\right] \mathrm{CH}_{3} \mathrm{OH}$ (1) } \\
\hline $\mathrm{Cu}(1)-\mathrm{O}(1)$ & 1. $956(3)$ & $\mathrm{Cu}(1 \mathrm{a})-\mathrm{O}(1)$ & $2.394(4)$ \\
\hline $\mathrm{Cu}(1)-\mathrm{O}(3)$ & $1.933(4)$ & $\mathrm{Cu}(1)-\mathrm{O}(7)$ & $1.975(4)$ \\
\hline $\mathrm{Cu}(1)-\mathrm{N}(3)$ & $2.008(4)$ & $\mathrm{Cu}(1) \cdots \mathrm{Cu}(1 \mathrm{~A})$ & 3.429 \\
\hline \multicolumn{4}{|l|}{ Bond angles } \\
\hline $\mathrm{Cu}(1)-\mathrm{O}(1)-\mathrm{Cu}(1 \mathrm{~A})$ & $103.3(2)$ & $\mathrm{O}(3)-\mathrm{Cu}(1)-\mathrm{O}(1)$ & $174.2(2)$ \\
\hline $\mathrm{O}(7)-\mathrm{Cu}(1)-\mathrm{N}(1)$ & $166.6(2)$ & $\mathrm{O}(1)-\mathrm{Cu}(1)-\mathrm{O}(7)$ & $90.7(2)$ \\
\hline $\mathrm{O}(3)-\mathrm{Cu}(1)-\mathrm{O}(7)$ & $88.6(2)$ & $\mathrm{O}(1)-\mathrm{Cu}(1)-\mathrm{O}(1 \mathrm{~A})$ & $76.7(2)$ \\
\hline $\mathrm{O}(3)-\mathrm{Cu}(1)-\mathrm{O}(1 \mathrm{~A})$ & $97.70(13)$ & $\mathrm{O}(7)-\mathrm{Cu}(1)-\mathrm{O}(1 \mathrm{~A})$ & $96.03(14)$ \\
\hline $\mathrm{O}(3)-\mathrm{Cu}(1)-\mathrm{N}(1)$ & $92.5(2)$ & $\mathrm{N}(1)-\mathrm{Cu}(1)-\mathrm{O}(1 \mathrm{~A})$ & $97.10(14)$ \\
\hline
\end{tabular}

$\left[\mathrm{Cu}\left(\mathrm{Cl}_{2} \mathrm{CHCO}_{2}\right)_{2}(\mathrm{NITpPy})_{2}\left(\mathrm{H}_{2} \mathrm{O}\right)\right](2)$

Bond lengths

$\begin{array}{llll}\mathrm{Cu}(1)-\mathrm{O}(1) & 1.970(4) & \mathrm{Cu}(1)-\mathrm{O}(3) & 1.956(4) \\ \mathrm{Cu}(1)-\mathrm{O}(9) & 2.282(5) & \mathrm{Cu}(1)-\mathrm{N}(1) & 2.027(5) \\ \mathrm{Cu}(1)-\mathrm{N}(4) & 2.018(5) & \mathrm{Cu}(2)-\mathrm{O}(10) & 1.966(4) \\ \mathrm{Cu}(2)-\mathrm{O}(12) & 1.967(4) & \mathrm{Cu}(2)-\mathrm{O}(18) & 2.256(6) \\ \mathrm{Cu}(2)-\mathrm{N}(7) & 2.020(5) & \mathrm{Cu}(2)-\mathrm{N}(10) & 2.021(5)\end{array}$

Bond angles

$\mathrm{O}(3)-\mathrm{Cu}(1)-\mathrm{N}(4)$

$171.8(2)$

$\mathrm{O}(1)-\mathrm{Cu}(1)-\mathrm{O}(3) \quad 170.6(2)$

$\mathrm{O}(3)-\mathrm{Cu}(1)-\mathrm{N}(1)$

$\mathrm{O}(3)-\mathrm{Cu}(1)-\mathrm{O}(9)$

$\mathrm{N}(4)-\mathrm{Cu}(1)-\mathrm{O}(9)$

$\mathrm{N}(7)-\mathrm{Cu}(2)-\mathrm{N}(10)$

$\mathrm{O}(12)-\mathrm{Cu}(2)-\mathrm{N}(7)$

$\mathrm{O}(10)-\mathrm{Cu}(2)-\mathrm{N}(10)$

$89.8(2)$

91.1(2)

$100.4(2)$

$95.8(2)$

$171.9(2)$

$88.9(2)$

$90.7(2)$

$\mathrm{N}(10)-\mathrm{Cu}(2)-\mathrm{O}(18)$

\section{$\mathrm{O}(1)-\mathrm{Cu}(1)-\mathrm{N}(4) \quad 88.1(2)$}

$\mathrm{O}(1)-\mathrm{Cu}(1)-\mathrm{N}(1) \quad 89.7(2)$

$\mathrm{O}(1)-\mathrm{Cu}(1)-\mathrm{O}(9) \quad 89.0(2)$

$\mathrm{N}(1)-\mathrm{Cu}(1)-\mathrm{O}(9) \quad 92.1(2)$

$\mathrm{O}(12)-\mathrm{Cu}(2)-\mathrm{O}(10) \quad 169.6(2)$

$\mathrm{O}(10)-\mathrm{Cu}(2)-\mathrm{N}(7) \quad 88.9(2)$

$\mathrm{N}(7)-\mathrm{Cu}(2)-\mathrm{O}(18) \quad 94.7(2)$

$\mathrm{O}(10)-\mathrm{Cu}(2)-\mathrm{O}(18) \quad 99.8(2)$

Table 3

Selected bond lengths $(\AA)$ and bond angles $\left(^{\circ}\right)$ for complexes 3 and $\mathbf{4}$

\begin{tabular}{|c|c|c|c|}
\hline \multicolumn{4}{|c|}{$\begin{array}{l}{\left[\mathrm{Cu}\left(\mathrm{Cl}_{3} \mathrm{CCO}_{2}\right)_{2}(\mathrm{NITpPy})_{2}\left(\mathrm{H}_{2} \mathrm{O}\right)\right](3)} \\
\text { Bond lengths }\end{array}$} \\
\hline $\mathrm{Cu}(1)-\mathrm{O}(1)$ & $1.959(5)$ & $\mathrm{Cu}(1)-\mathrm{O}(3)$ & $1.963(5)$ \\
\hline $\mathrm{Cu}(1)-\mathrm{N}(2)$ & $2.006(6)$ & $\mathrm{Cu}(1)-\mathrm{N}(1)$ & $2.003(6)$ \\
\hline $\mathrm{Cu}(1)-\mathrm{O}(9)$ & $2.250(8)$ & $\mathrm{Cu}(2)-\mathrm{O}(10)$ & $1.962(6)$ \\
\hline $\mathrm{Cu}(2)-\mathrm{O}(12)$ & $1.966(6)$ & $\mathrm{Cu}(2)-\mathrm{N}(7)$ & $2.005(6)$ \\
\hline $\mathrm{Cu}(2)-\mathrm{O}(18)$ & $2.257(5)$ & $\mathrm{Cu}(2)-\mathrm{N}(8)$ & $2.011(6)$ \\
\hline \multicolumn{4}{|l|}{ Bond angles } \\
\hline $\mathrm{O}(1)-\mathrm{Cu}(1)-\mathrm{O}(3)$ & $171.3(2)$ & $\mathrm{N}(1)-\mathrm{Cu}(1)-\mathrm{N}(2)$ & $170.9(3)$ \\
\hline $\mathrm{O}(1)-\mathrm{Cu}(1)-\mathrm{O}(9)$ & $90.9(3)$ & $\mathrm{O}(1)-\mathrm{Cu}(1)-\mathrm{N}(1)$ & $88.2(2)$ \\
\hline $\mathrm{O}(3)-\mathrm{Cu}(1)-\mathrm{N}(2)$ & $90.8(2)$ & $\mathrm{O}(1)-\mathrm{Cu}(1)-\mathrm{N}(1)$ & $90.3(2)$ \\
\hline $\mathrm{O}(3)-\mathrm{Cu}(1)-\mathrm{N}(1)$ & $89.4(2)$ & $\mathrm{O}(3)-\mathrm{Cu}(1)-\mathrm{O}(9)$ & $97.8(3)$ \\
\hline $\mathrm{O}(10)-\mathrm{Cu}(2)-\mathrm{O}(12)$ & $171.4(2)$ & $\mathrm{N}(7)-\mathrm{Cu}(2)-\mathrm{N}(8)$ & $171.7(3)$ \\
\hline $\mathrm{O}(12)-\mathrm{Cu}(2)-\mathrm{N}(7)$ & $90.7(2)$ & $\mathrm{O}(10)-\mathrm{Cu}(2)-\mathrm{N}(7)$ & $89.0(2)$ \\
\hline $\mathrm{O}(10)-\mathrm{Cu}(2)-\mathrm{O}(18)$ & $98.4(2)$ & $\mathrm{O}(12)-\mathrm{Cu}(2)-\mathrm{O}(18)$ & $90.2(2)$ \\
\hline $\mathrm{N}(7)-\mathrm{Cu}(2)-\mathrm{O}(18)$ & $92.0(2)$ & $\mathrm{N}(8)-\mathrm{Cu}(2)-\mathrm{O}(18)$ & $96.3(2)$ \\
\hline \multicolumn{4}{|c|}{$\begin{array}{l}\left.\left[\mathrm{Cu}\left(\mathrm{Cl}_{2} \mathrm{CHCO}\right)_{2}\right)_{2}(\mathrm{NITmPy})_{2}\left(\mathrm{H}_{2} \mathrm{O}\right)_{2}\right] \text { (4) } \\
\text { Bond lengths }\end{array}$} \\
\hline $\mathrm{Cu}-\mathrm{O}(3)$ & $1.964(3)$ & $\mathrm{Cu}-\mathrm{O}(5)$ & $2.575(3)$ \\
\hline $\mathrm{Cu}-\mathrm{N}(1)$ & $1.999(3)$ & & \\
\hline \multicolumn{4}{|l|}{ Bond angles } \\
\hline $\mathrm{O}(3)-\mathrm{Cu}-\mathrm{O}(3 \mathrm{~A})$ & 180.0 & $\mathrm{~N}(1)-\mathrm{Cu}-\mathrm{N}(1 \mathrm{~A})$ & 180.0 \\
\hline $\mathrm{O}(3)-\mathrm{Cu}-\mathrm{N}(1 \mathrm{~A})$ & $90.70(13)$ & $\mathrm{O}(3 \mathrm{~A})-\mathrm{Cu}-\mathrm{N}(1 \mathrm{~A})$ & $89.30(13)$ \\
\hline $\mathrm{O}(3)-\mathrm{Cu}-\mathrm{N}(1)$ & $89.30(13)$ & $\mathrm{O}(3)-\mathrm{Cu}-\mathrm{O}(5)$ & $85.29(12)$ \\
\hline $\mathrm{N}(1)-\mathrm{Cu}-\mathrm{O}(5)$ & $89.96(13)$ & & \\
\hline
\end{tabular}

collection, crystallographic data and reduction are summarized in Table 1.

The structures were solved by the direct method and refined by full-matrix least-squares based on $F^{2}$ using the SHELX-93 computer program package [25]. Reliability factors were defined as $R_{1}=\Sigma\left(\left|F_{\mathrm{o}}\right|-\mid F_{\mathrm{c}}\right) / \Sigma\left|F_{\mathrm{o}}\right|$ and the function minimized was $R_{\mathrm{w}}=\left[\Sigma w\left(F_{\mathrm{o}}^{2}-F_{\mathrm{c}}^{2}\right)^{2} /\right.$ $\left.\left.\Sigma w\left(F_{\mathrm{o}}\right)^{4}\right]^{1 / 2}\right]$, where in the least-squares calculation the unit weight was used. All non-hydrogen atoms were refined anisotropically. Selected bond distances and angles of 1, 2 and 3, 4 are listed in Tables 2 and 3, respectively.

\section{Results and discussion}

\subsection{Structures of complexes $\mathbf{1}-\mathbf{4}$}

The crystal structure of $\left[\mathrm{Cu}_{2}\left(\mu-\mathrm{ClCH}_{2} \mathrm{CO}_{2}\right)_{2}\left(\mathrm{ClCH}_{2}\right.\right.$ $\left.\left.\mathrm{CO}_{2}\right)_{2}(\mathrm{NITpPy})_{2}\left(\mathrm{H}_{2} \mathrm{O}\right)_{2}\right] \mathrm{CH}_{3} \mathrm{OH}$ (1) is illustrated in Fig. 1. In this dinuclear compound, the four oxygen atoms and one nitrogen atom bound to the copper ion are located at the apices of a distorted square pyramid. The basal coordination sites are occupied by two oxygen atoms of two $\mathrm{ClCH}_{2} \mathrm{CO}_{2}^{-}$, one oxygen atom of $\mathrm{H}_{2} \mathrm{O}$, and one nitrogen atom of NITpPy groups, while the axial position is occupied by the bridging oxygen atom of a $\mu-\mathrm{ClCH}_{2} \mathrm{CO}_{2}^{-}$group. The $\mathrm{Cu}$ (II) ion is not coplanar with the basal plane, with a displacement of $0.35 \AA$ out of the basal plane. The copper-oxygen distance $(\AA)$ of $\mathrm{Cu}(1)-\mathrm{O}(1 \mathrm{~A})$ (axial bridging acetate) 2.394(4) is larger than that of $\mathrm{Cu}(1)-\mathrm{O}(3)$ (acetate) 1.933(4), $\mathrm{Cu}(1)-\mathrm{O}(1)$ (basal bridging acetate) 1.965(3), or $\mathrm{Cu}(1)-\mathrm{O}(7)$ (water) 1.975(4). The $\mathrm{Cu}_{2} \mathrm{O}_{2}$ core is planar and the $\mathrm{Cu}-\mathrm{Cu}$ separation is 3.429(4) $\AA$. The fragment $\mathrm{O}(5)-\mathrm{N}(3)-\mathrm{C}(6)-\mathrm{N}(2)-\mathrm{O}(6) \quad[\mathrm{N}(3)-\mathrm{O}(5) \quad 1.296(5)$ and $\mathrm{N}(2)-\mathrm{O}(6)$ 1.274(6) $\AA$ ] is nearly planar but forms a dihedral angle of $34.4^{\circ}$ with the plane of the pyridyl ring.

Complexes 2 and 3 consist of two crystallographically independent mononuclear $\mathrm{Cu}(1)$ and $\mathrm{Cu}(2)$ complexes with the same five coordination core of $\mathrm{N}_{2} \mathrm{O}_{3}$ and square-pyramidal coordination geometry. Due to their structural isomorphism, the corresponding bond distances and angles of $\mathrm{Cu}(1)$ and $\mathrm{Cu}(2)$ complexes are not significantly different, here only the structures around the $\mathrm{Cu}(1)$ coordination sphere in 2 (Fig. 2) and 3 (Fig. 3) are discussed. The mean $\mathrm{Cu}-\mathrm{O}$ (monodentate acetate) bond distances $[\mathrm{Cu}(1)-\mathrm{O}(1)$ and $\mathrm{Cu}(1)-\mathrm{O}(3)]$ for 2 and 3 are 1.963(5) and 1.961(5) $\AA$, respectively, and these are shorter than the mean bond distances of $\mathrm{Cu}(1)-\mathrm{N}$ (pyridyl) 2.023(5) for $\mathbf{2}$ and 2.020(6) $\AA$ for $\mathbf{3}$. The $\mathrm{O}(5)-\mathrm{N}(2)-\mathrm{C}(6)-\mathrm{N}(3)-\mathrm{O}(6)$ and $\mathrm{O}(7)-\mathrm{N}(5)-$ $\mathrm{C}(18)-\mathrm{N}(6)-\mathrm{O}(8)$ moieties in $\mathbf{2}$ and $\mathbf{3}$ are as expected coplanar, but form mean dihedral angles of $11.08^{\circ}$ for 2 and $20.65^{\circ}$ for 3 with the plane of pyridyl ring. 
The structure of complex 4 is shown in Fig. 4, two pyridyl nitrogen atoms are coordinated to the copper(II) ion in the trans configuration. The coordination sphere of the $\mathrm{Cu}(1)$ ion is a distorted octahedron in which the bond lengths are $\mathrm{Cu}(1)-\mathrm{O}(3)=1.961(6) \AA$, $\mathrm{Cu}(1)-\mathrm{O}(3 \mathrm{~A})=1.963(6) \AA, \mathrm{Cu}(1)-\mathrm{N}(1)=1.962(9) \AA$, $\mathrm{Cu}(1)-\mathrm{N}(1 \mathrm{~A})=2.013(7) \quad \AA, \quad \mathrm{Cu}(1)-\mathrm{O}(5)\left(\mathrm{H}_{2} \mathrm{O}\right)=$ $2.567(7) \AA$ and $\mathrm{Cu}(1)-\mathrm{O}(10)\left(\mathrm{H}_{2} \mathrm{O}\right)=2.585(8) \AA$, and the bond angles between $\mathrm{Cu}(1)-\mathrm{O}(3)$ and the other ligands are nearly $90^{\circ}$ (Table 3 ). As the elongation axis is through $\mathrm{O}(5)-\mathrm{Cu}(1)-\mathrm{O}(10)\left(178.9(4)^{\circ}\right)$, this indicates that the lobes of the magnetic orbital $\mathrm{d}_{x^{2}-y^{2}}$, which is orthogonal to the $\mathrm{d}_{z^{2}}$ orbital of $\mathrm{Cu}$ (II) ion, are directed toward the carboxylate oxygen atoms and the pyridyl nitrogen atoms. It is worthy of note that the distances of $\mathrm{O}(5) \cdots \mathrm{O}\left(4^{\prime}\right)$ (carboxylate) and $\mathrm{O}(10) \cdots \mathrm{O}(4)$ (carboxy- late) are 2.697(2) and 2.673(2) $\AA$, indicative of a hydrogen bond within. The fragments $\mathrm{O}(1)-\mathrm{N}(2)-\mathrm{C}(6)-$ $\mathrm{N}(3)-\mathrm{O}(2)$ and $\mathrm{O}(1 \mathrm{~A})-\mathrm{N}(2 \mathrm{~A})-\mathrm{C}(6 \mathrm{a})-\mathrm{N}(3 \mathrm{~A})-\mathrm{O}(2 \mathrm{~A})$ are as expected coplanar, but form dihedral angles 24.91 and $25.26^{\circ}$, respectively, with the plane of the pyridyl ring.

\subsection{Magnetic properties of complexes $1-4$}

The $\chi_{\mathrm{m}} T$ value at $300 \mathrm{~K}$ of $1,1.17 \mathrm{~cm}^{3} \mathrm{~K} \mathrm{~mol}^{-1}$, is slightly lower than the value expected for four non-coupled spins $S=1 / 2$, two for the dicopper(II) ions and two for the NITpPy radicals in 1. In Fig. 5, the variation of $\chi_{\mathrm{m}} T$ with $T$ is shown over the temperature range $300-2 \mathrm{~K}$. The plot reveals three domains: (i) from $300 \mathrm{~K}$ to about $100 \mathrm{~K}, \chi_{\mathrm{m}} T$ rapidly decreases

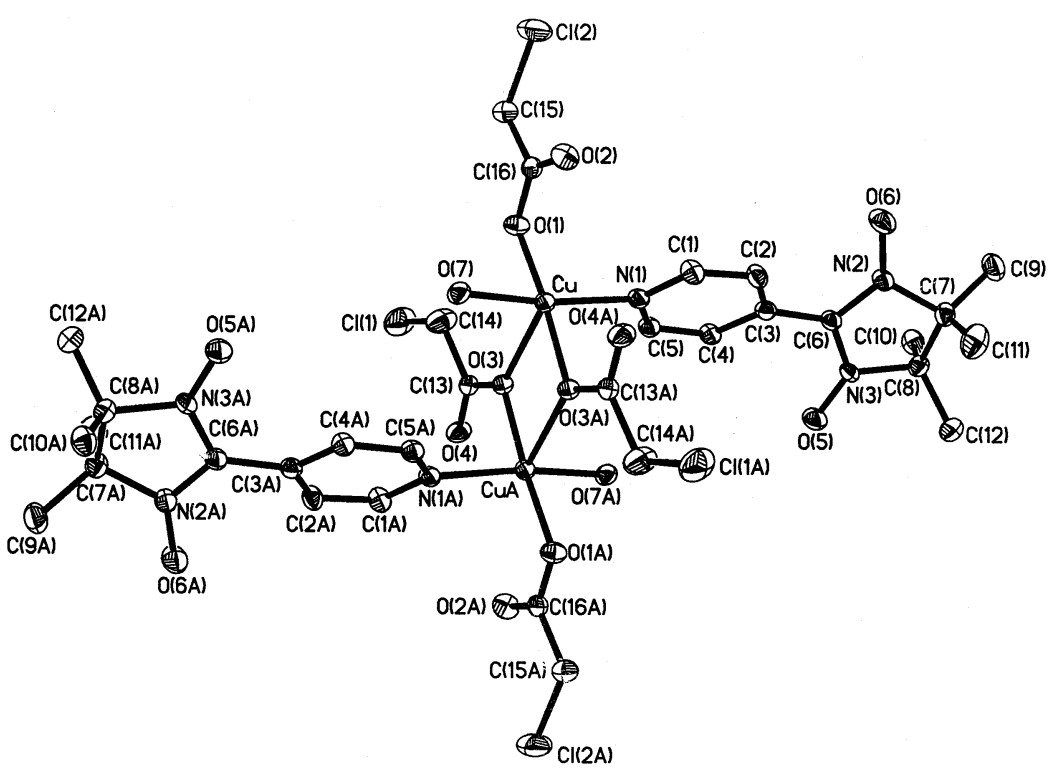

Fig. 1. Structure of $\left[\mathrm{Cu}_{2}\left(\mu-\mathrm{ClCH}_{2} \mathrm{CO}_{2}\right)_{2}\left(\mathrm{ClCH}_{2} \mathrm{CO}_{2}\right)_{2}(\mathrm{NITpPy})_{2}\left(\mathrm{H}_{2} \mathrm{O}\right)_{2}\right] \mathrm{CH}_{3} \mathrm{OH}$ (1) with the atom numbering scheme; $30 \%$ probability ellipsoids are shown.

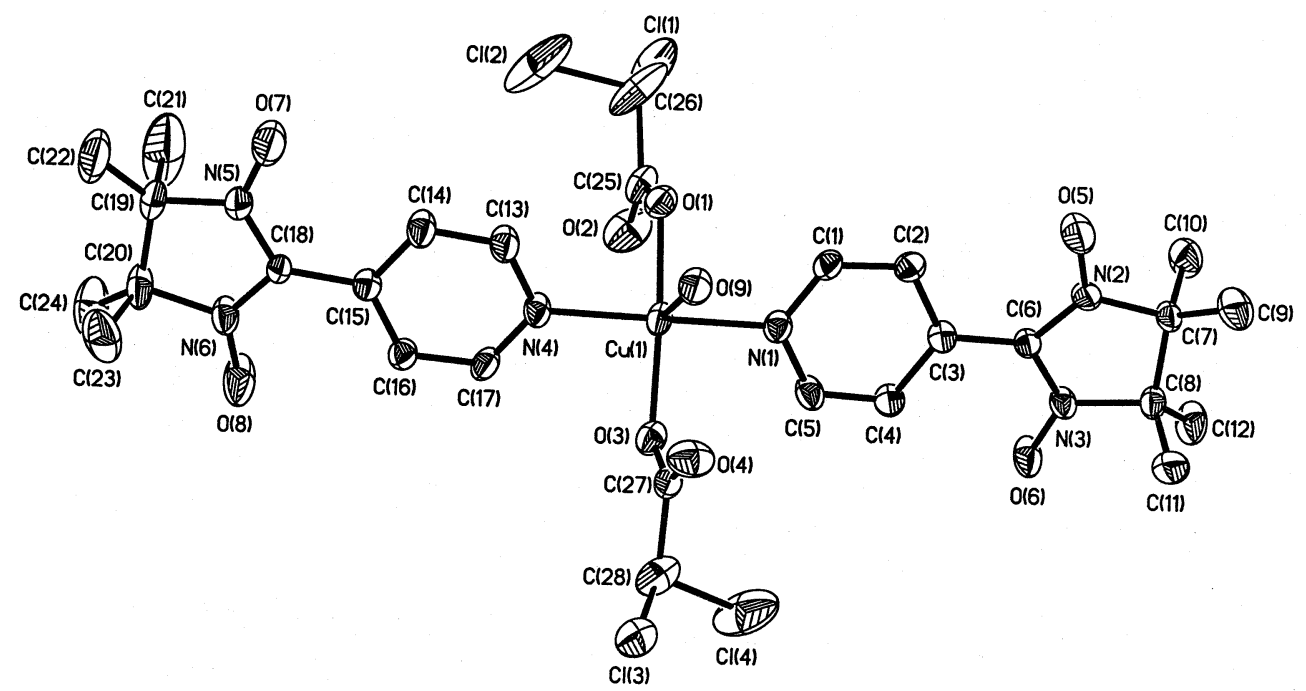

Fig. 2. Structure of $\left[\mathrm{Cu}\left(\mathrm{Cl}_{2} \mathrm{CHCO}_{2}\right)_{2}(\mathrm{NITpPy})_{2}\left(\mathrm{H}_{2} \mathrm{O}\right)\right]$ (2). Details as in Fig. 1. 


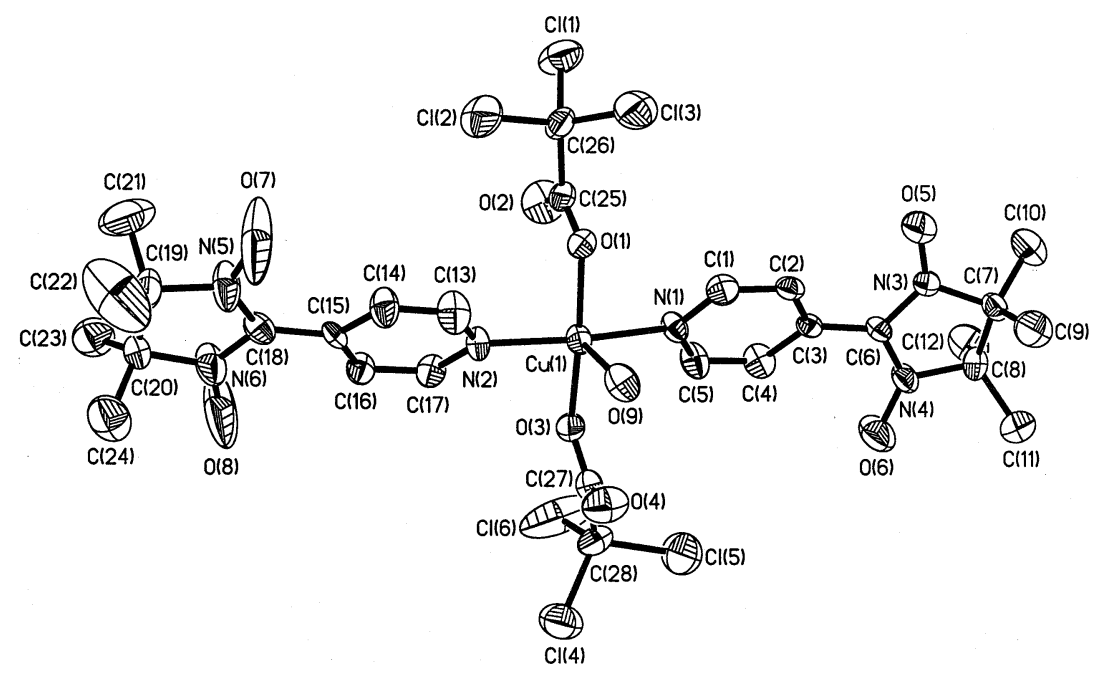

Fig. 3. Structure of $\left[\mathrm{Cu}\left(\mathrm{Cl}_{3} \mathrm{CCO}_{2}\right)_{2}(\mathrm{NITpPy})_{2}\left(\mathrm{H}_{2} \mathrm{O}\right)\right]$ (3). Details as in Fig. 1.

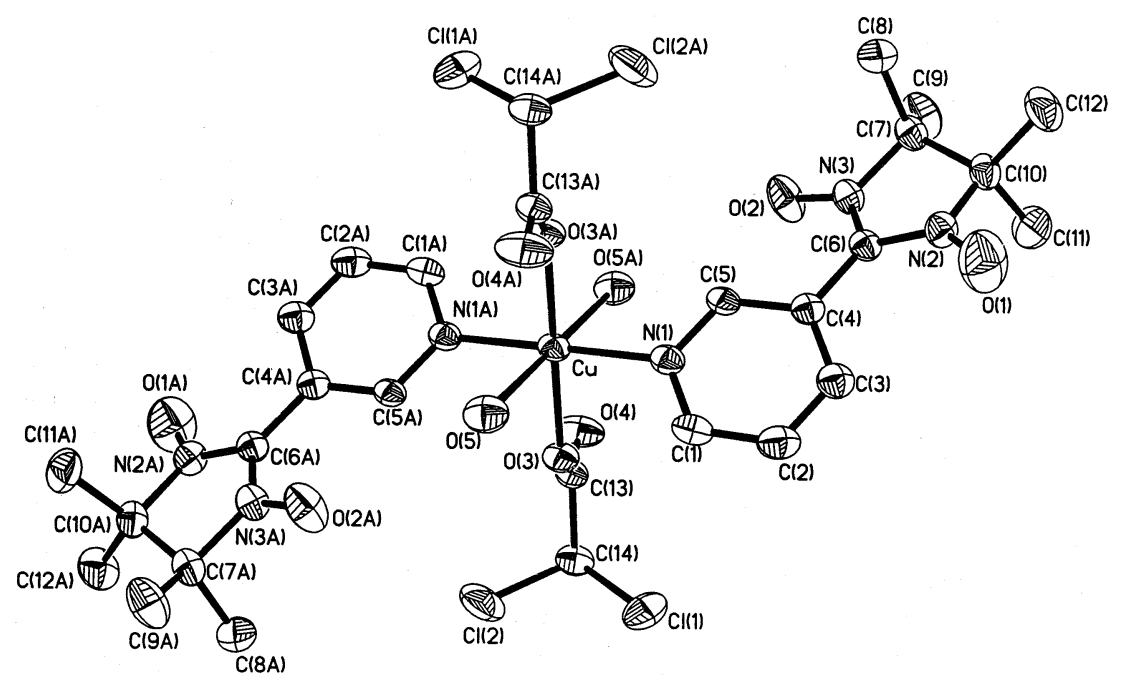

Fig. 4. Structure of $\left[\mathrm{Cu}\left(\mathrm{Cl}_{2} \mathrm{CHCO}_{2}\right)_{2}(\mathrm{NITmPy})_{2}\left(\mathrm{H}_{2} \mathrm{O}\right)_{2}\right](4)$. Details as in Fig. 1.

from a value of $1.17 \mathrm{~cm}^{3} \mathrm{~K} \mathrm{~mol}^{-1}\left(3.06 \mu_{\mathrm{B}}\right)$ to a value of about $0.80 \mathrm{~cm}^{3} \mathrm{~K} \mathrm{~mol}^{-1}$, larger than that for two coupled $S=1 / 2$ spin states; (ii) between approximately 100 and $25 \mathrm{~K}$, the value of $\chi_{\mathrm{m}} T$ gradually decreases with decreasing temperature, and (iii) below $25 \mathrm{~K}, \chi_{\mathrm{m}} T$ decreases to $0.46 \mathrm{~cm}^{3} \mathrm{~K} \mathrm{~mol}^{-1}\left(1.92 \mu_{\mathrm{B}}\right)$ as the temperature approaches $2 \mathrm{~K}$. In addition, for the plot of $\chi_{\mathrm{m}}^{-1}$ versus temperature, the range 100-2 K essentially follows the Curie-Weiss law with values for the Curie constant $C=0.39 \mathrm{~cm}^{3} \mathrm{~mol}^{-1}$ and Weiss constant $\theta=$ $-1.63 \mathrm{~K}$.

The crystal structure of complex 1 consists of a carboxy-bridged dinuclear $\mathrm{Cu}(\mathrm{II})$ and copper-nitroxyl units, in which strong intramolecular $\mathrm{Cu}(1)-\mathrm{Cu}(1 \mathrm{a})$ magnetic interactions and weak intramolecular coppernitroxy magnetic couplings are expected to occur in the complex. Therefore, we assumed that the organic free radicals behave as isolated $S=1 / 2$ spins. Accordingly, the variation of the $\chi_{\mathrm{m}} T$ product was attributed, to a large extent, to the pair of exchange-coupled copper(II) ions and to the two isolated NITpPy radicals. Finally, an approximate fit is performed by using Eq. (1) for complex 1:

$\chi_{\mathrm{m}}=\chi_{1}+2 \chi_{2}+N_{\alpha}$

$\chi_{1}=\left(2 N g^{2} \mu_{\mathrm{B}}^{2} / k T\right)[3+\exp (-2 J / k T)]^{-1}$

$\chi_{2}=C / T$

The best fit with $J=-170 \mathrm{~cm}^{-1}, g=2.0, C=0.39$ $\mathrm{cm}^{3} \mathrm{~mol}^{-1}$ and $N_{\alpha}=5.6 \times 10^{-5} \mathrm{~cm}^{3} \mathrm{~mol}^{-1}$ for $\mathbf{1}$ is obtained as the solid line in Fig. 5. This result again shows a very weak antiferromagnetic interaction through the $\mathrm{NITpPy}-\mathrm{Cu}$ moieties. In this regard, it is noteworthy that the nitroxide moiety forms a large dihedral angle of $34.4^{\circ}$ with the plane of the pyridyl 
ring in the NITpPy radical, resulting in difficult spinpolarization of $\pi^{*}$ of the NO group in the radical.

As shown in Fig. 6, The values of $\chi_{\mathrm{m}} T$ at $300 \mathrm{~K}$ for complexes 2 and 3 are 1.02 and $1.00 \mathrm{~cm}^{3} \mathrm{~K} \mathrm{~mol}^{-1}$, respectively, which are slightly lower than the sum of the Curie constants $\left(1.11 \mathrm{~cm}^{3} \mathrm{~K} \mathrm{~mol}^{-1}\right)$ of the three isolated $S=1 / 2$ spins. When the systems are cooled down from 300 to approximately $100 \mathrm{~K}$, the values of $\chi_{\mathrm{m}} T$ for complexes $\mathbf{2}$ and $\mathbf{3}$ are slightly decreased, and below approximately $100 \mathrm{~K}, \chi_{\mathrm{m}} T$ decreases rapidly reaching values of 0.26 and $0.19 \mathrm{~cm}^{3} \mathrm{~K} \mathrm{~mol}^{-1}$, respectively, indicating the presence of weak antiferromagnetic exchange interactions between the magnetic sites.

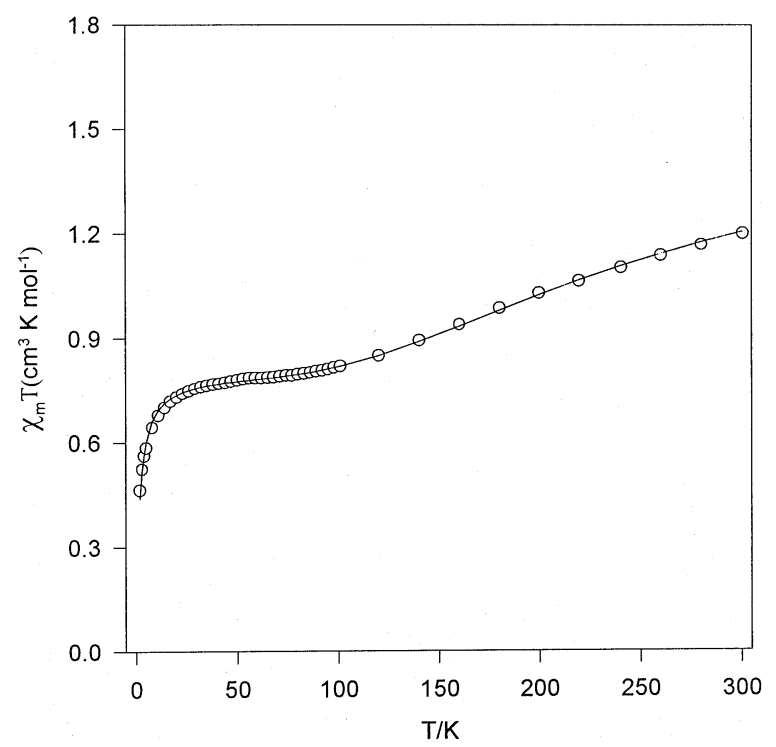

Fig. 5. Temperature-dependence of $\chi_{\mathrm{m}} T$ for complex 1 . The solid line represents the values calculated with parameters reported in the text.

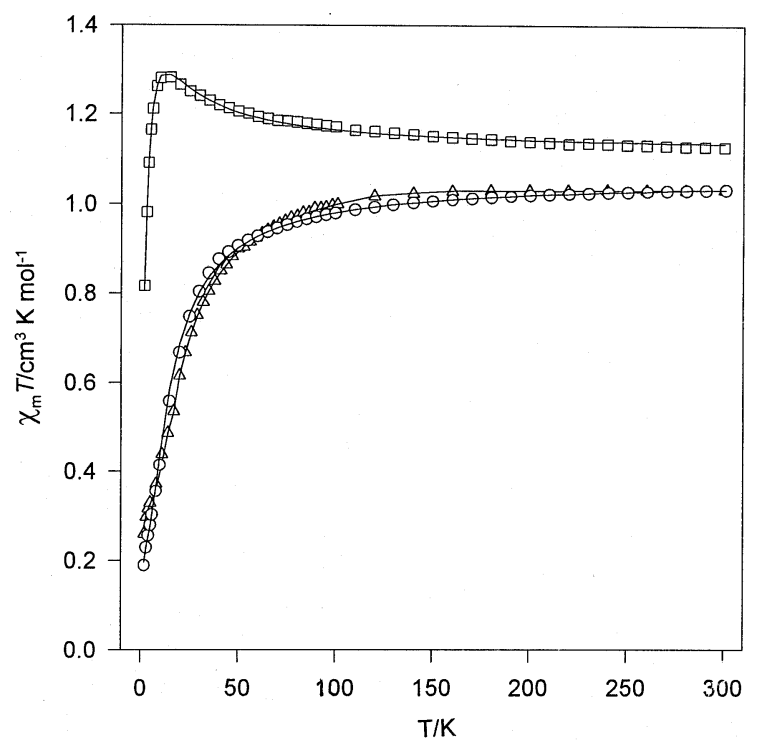

Fig. 6. Temperature-dependence of $\chi_{\mathrm{m}} T(-\triangle-)$ for $\mathbf{2},(-\bigcirc-)$ for 3 and $(-\square-$ ) for 4 . The solid lines represent the values are calculated with the parameters reported in the text.
Based on the results of structural studies, the nitroxide moiety in complexes $\mathbf{2}$ and $\mathbf{3}$ forms low dihedral angles of 10.08 and $20.65^{\circ}$, respectively, with the plane of the pyridyl ring in the NITpPy radical, resulting in an easy $\pi^{*}$ spin-polarization of the NO group in the radical. Therefore, the magnetic data for complexes $\mathbf{2}$ and 3 were fitted by considering a central symmetric linear of three $S=1 / 2$ spins, $S_{1}-S_{2}-S_{3}$, where $S_{1}$ and $S_{3}$ refer to the nitroxide sites and $S_{2}$ refers to the copper(II) ion. Eq. (2) [16] for this linear three $S=1 / 2$ spins system was applied and fitted to the observed $\chi_{\mathrm{m}} T-T$ plots for complexes $\mathbf{2}$ and $\mathbf{3}$ by means of a least-squares method. All the symbols have their usual meaning:

$\chi_{\mathrm{m}} T=\left(N \mu_{\mathrm{B}}^{2} g^{2} T / 3 k(T-\theta)\right)[A / B]$

$A=60 \exp (3 J / T)+6 \exp (2 J / T)+6$

$B=4(4 \exp (3 J / T)+2 \exp (2 J / T)+2)$

The best-fitted values of the parameters are: $J=$ $-11.5 \mathrm{~cm}^{-1}, \theta=-0.66 \mathrm{~K}$, and $g=1.98$ for complex 2; $J=-13 \mathrm{~cm}^{-1}, \theta=-0.79 \mathrm{~K}$ and $g=1.97$. A solid line in Fig. 6 represents the theoretical curve.

We have performed room temperature EPR spectra (at $9.75 \mathrm{GHz}$ ) for complexes 2 and 3 in $\mathrm{CH}_{2} \mathrm{Cl}_{2}$ solutions and these show major lines in the ratio $1: 2: 3: 2: 1$ with $g=2.01$, and nitrogen hyperfine coupling constants $a^{\mathrm{N}}=7.72$ and $7.70 \mathrm{G}\left(\mathrm{G}=10^{-4} \mathrm{~T}\right)$, respectively, as expected for coupling with two identical nitrogens of the NO groups of NITpPy; no signal from the copper(II) ions was observed. Here we used the formula of $g=(8 / 15) g_{\mathrm{r}}($ radical $)+(7 / 15) g_{\mathrm{Cu}}$, and we obtained the same $g_{\mathrm{Cu}}$ value of 1.97 for complexes $\mathbf{2}$ and $\mathbf{3}$.

A plot of $\chi_{\mathrm{m}} T-T$ for complex 4 is shown in Fig. 6 . When the temperature was decreased from 300 to $2 \mathrm{~K}$, the $\chi_{\mathrm{m}} T$ values $\left(1.10 \mathrm{~cm}^{3} \mathrm{~K} \mathrm{~mol}^{-1}\right.$ at $\left.300 \mathrm{~K}\right)$ increased gradually, reached a maximum $\left(1.28 \mathrm{~cm}^{3} \mathrm{~K} \mathrm{~mol}^{-1}\right.$ at $15 \mathrm{~K})$, characteristic of intramolecular magnetic exchange interactions, and then decreased.

The structural study of complex 4 shows the low mean dihedral angle of $25.17^{\circ}$ between the nitroxide moiety and pyridyl ring, so that easy spin-polarization can take place in the NITmPy radical. The theoretical expression for the magnetic susceptibility of the system also uses Eq. (2), leading to the following parameters: $g=\left(g_{\mathrm{r}}+g_{\mathrm{Cu}}\right) / 2=2.0, J=12.0 \mathrm{~cm}^{-1}$ and $\theta=-1.6 \mathrm{~K}$.

Since the fitted magnetic data of complex 4 provide evidence for a weak intramolecular ferromagnetic interaction, one must consider a possible mechanism for the exchange interaction between the radical NITmPy and $\mathrm{Cu}$ (II) ion. An acceptable mechanism is suggested by McConnell [26] for the interpretation of the ferromagnetic behavior of the $N$-oxyl $N^{\prime}$-oxides [27] and $N$-terabutylaminoxyl radical [28]. According to this model a spin distribution arising from intramolecular spin polarization of the adjacent atoms leads to alternating 


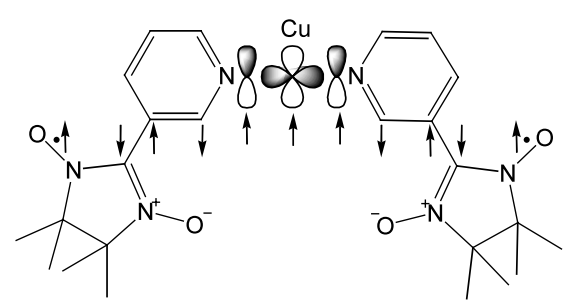

Scheme 2.

positive and negative spin density on the carbon backbone of the radical ligands. A schematic representation of the alternating spin densities for $\mathbf{4}$ is given in Scheme 2. The magnetic orbital $\mathrm{d}_{x^{2}-y^{2}}$, orthogonal to the elongated axis of octahedral $\mathrm{Cu}(\mathrm{II})$, is directed to the two nitrogen atoms of the pyridine groups. The positive spin density on the NO site of one NITmPy moiety induces negative spin density on the neighboring carbon atom due to a spin polarization, which in turn induces positive spin density on the $\mathrm{Cu}$ (II) ion and on the NO site of the other adjacent NITmPy moiety.

\section{Supplementary material}

Crystallographic data for the structural analyses have been deposited with the Cambridge Crystallographic Data Centre, CCDC Nos. 161298, 161308, 161309 and 161299 for compounds $\mathbf{1}-\mathbf{4}$, respectively. Copies of this information may be obtained free of charge from The Director, CCDC, 12 Union Road, Cambridge, CB2 1EZ, UK (fax: + 44-1233-336033; e-mail: de-posit@ ccdc.cam.ac.uk or www: http://www.ccdc.cam.ac.uk).

\section{Acknowledgements}

This work is supported by grants from the National Science Council of Taiwan.

\section{References}

[1] A. Caneschi, D. Gatteschi, P. Rey, Progr. Inorg. Chem. 39 (1991) 331.

[2] A. Caneschi, P. Chiesi, L. David, F. Ferraro, D. Gatteschi, R. Sessoli, Inorg. Chem. 32 (1993) 1445.

[3] K. Inoue, H. Iwamula, J. Am. Chem. Soc. 116 (1994) 3173.

[4] V.I. Orcharenko, F.L. de Panthou, N.V. Reznikov, P. Rey, R.Z. Sagdeev, Inorg. Chem. 34 (1995) 2263.
[5] F.A. Villamena, M.H. Dickman, D.R. Crist, Inorg. Chem. 37 (1998) 1454.

[6] K. Fegy, N. Sanz, D. Luneau, E. Belorizky, P. Rey, Inorg. Chem. 37 (1998) 4518.

[7] K. Fegy, D. Luneau, E. Belorizky, M. Novac, J.L. Tholence, C. Paulsen, T. Ohm, P. Rey, Inorg. Chem. 37 (1998) 4524.

[8] D. Luneau, F.M. Romero, R. Ziessel, Inorg. Chem. 37 (1998) 5078 .

[9] R. Ruiz, J. Faus, F. Lloret, M. Julve, Y. Journaux, Coord. Chem. Rev. 193-195 (1999) 1069.

[10] C. Banelli, A. Caneschi, D. Gatteschi, L. Pardi, Inorg. Chem. 31 (1992) 741.

[11] D. Luneau, G. Risoan, P. Rey, A. Grand, A. Caneschi, D. Gatteschi, J. Laugier, Inorg. Chem. 32 (1993) 5616.

[12] F.L. de Panthou, E. Belorizky, R. Calemczuk, D. Luneau, C. Marcenant, E. Ressouche, P. Turek, P. Rey, J. Am. Chem. Soc. 115 (1995) 9095.

[13] A. Yamaguchi, T. Okuno, K. Awaga, Bull. Chem. Soc. Jpn. 69 (1996) 875.

[14] J.P. Sutter, M. Fettouhi, L. Li, C. Michaut, L. Ouahab, O. Kahn, Angew. Chem., Int. Ed. Engl. 35 (1996) 2133.

[15] H. Oshio, T. Watanabe, A. Ohto, T. Ito, T. Ikoma, S. TeroKubota, Inorg. Chem. 36 (1997) 3014.

[16] Y. Ishimaru, M. Kitano, H. Kumada, N. Koga, H. Iwamura, Inorg. Chem. 37 (1998) 2273.

[17] C.J. Lee, C.H. Huang, H.H. Wei, Y.H. Liu, G.H. Lee, Y. Wang, J. Chem. Soc., Dalton Trans. (1998) 171.

[18] Z.H. Jiang, B.W. Sun, D.Z. Liao, G.L. Wang, F. Dahan, J.P. Tuchagues, Inorg. Chim. Acta 279 (1998) 69.

[19] Y.H. Chung, H.H. Wei, Inorg. Chem. Commun. 2 (1999) 269.

[20] (a) G.R. Eaton, S.S. Eaton, Acc. Chem. Res. 21 (1988) 107; (b) H.O. Stumpf, L. Ouahab, Y. Pei, D. Grandjean, O. Kahn, Science 261 (1993) 447;

(c) L.B. Volodarsky, V.A. Reznikov, V.I. Ovcharenko, Synthetic Chemistry of Stable Nitroxides, CRC Press, Boca Raton, FL, 1994.

[21] (a) H.M. McConnell, J. Chem. Phys. 39 (1963) 1910;

(b) D.A. Dougherty, Acc. Chem. Res. 24 (1991) 88;

(c) A. Rajca, Chem. Rev. 94 (1994) 871.

[22] (a) D. Lanchem, T.W. Wittag, J. Chem. Soc. C (1966) 2300; (b) E.F. Ullmann, L. Call, J.H. Osiecki, J. Org. Chem. 35 (1970) 3623.

[23] (a) C. Mehrotra, R.C. Bohra, Metal Carboxylates, Academic Press, New York, 1983;

(b) P. de Meester, S.R. Fletsher, A.C. Skapski, J. Chem. Soc., Dalton Trans. (1973) 2575.

[24] R.L. Carlin, Magnetochemistry, Springer, Germany, 1986, p. 3.

[25] G.M. Sheldrick, SHELXL-93, Program for the Refinement of Crystal Structures; University of Göttingen, Göttingen, Germany, 1993.

[26] H.M. McConnell, J. Chem. Phys. 39 (1963) 1910.

[27] (a) J. Cirujeda, M. Mas, E. Molins, F.L. de Panthou, J. Laugier, J.G. Park, C. Pauson, P. Rey, C. Rovira, J. Veciana, J. Chem. Soc., Chem. Commun. (1995) 709;

(b) J. Veciana, J. Cirujeda, C. Rovira, J. Vidal-Gancedo, Adv. Mater. 7 (1995) 221;

(c) K. Togashi, R. Imachi, K. Tomioka, H. Tsuboi, Y. Ishida, T. Nogami, N. Takeda, M. Ishikawa, Bull. Chem. Soc. Jpn. 49 (1994) 3975.

[28] Y. Ishimaru, M. Kitano, H. Kumada, N. Koga, H. Iwamura, Inorg. Chem. 37 (1998) 2273. 